\title{
CRM 2.0 sebagai Strategi Layanan Rumah Sakit Kelas C terhadap Pasien BPJS -KIS
}

\author{
Dhana Sudana ${ }^{1}$, Andi W.R. Emanuel ${ }^{2}$ \\ 1,2Magister Teknik Informatika Universitas Atma Jaya Yogaykarta \\ Jl. Babarsari No.44, Yogyakarta 55281 \\ 1e-mail: dhanamoriaud@gmail.com \\ 2e-mail: andi.emanuel@uajy.ac.id
}

\begin{abstract}
Abstrak
Pelayanan asuransi dari pemerintah (JKN) melalui badan penyelenggara BPJS-KIS saat ini merupakan bagian besar rumah sakit yang ada di Indonesia. Meskipun begitu masih banyak peserta BPJS-KIS yang masih belum mengetahui tatacara menggunakan asuransi JKN di rumah sakit. Pihak rumah sakit melalui Customer Relationship Management (CRM) seharusnya bisa memberikan informasi tersebut melalui website atau melalui media social RS. Tujuan: Penelitian ini memberikan usulan model penyampaian informasi melalui model social-CRM sebagai bentuk ikatan antara pasien asuransi pemeritah BPJS-KIS terhadap rumah sakit kelas C di Yogyakarta sebagai rujukan pertama Faskes 1. Method: peneliti mengambil contoh website rumah sakit kelas $\mathrm{C}$ di Yogyakarta baik rumah sakit pemerintah, organisasi sosial dan swasta. Dari website rumah sakit tersebut kami menganalisis seberapa besar bentuk informasi tentang asuransi dan service RS terhadap pasien BPJS_KIS. Kami memberikan usulan desain model social-CRM atau CRM-2.0 untuk rumah sakit dengan memasukan informasi BPJS-KIS dalam menu khusus. Dalam model social CRM ini kami memberikan usulan fitur yang mudah di akses peserta/ pasien KIS yang di hubungan dengan social media RS seperti Facebook, twiter instagram dll. Hasil: Bentuk usulan social CRM rumah sakit yang diperuntukan masyarakat pengguna asuransi BPJS -KIS yang dapat diakses melalui social media RS.
\end{abstract}

Katakunci: Social-CRM Model, Penjaminan Mutu dan Pelayanan RS, Pasien BPJS-KIS

\begin{abstract}
Government insurance services (JKN) through BPJS-KIS administrators are currently a large part of hospitals in Indonesia. Even so, there are still many BPJS-KIS participants who still do not know the procedures for using JKN insurance in hospitals. Hospitals through Customer Relationship Management (CRM) should be able to provide that information through the website or through social media hospitals. Objective: This study proposes a model for delivering information through a social-CRM model as a form of bond between BPJS-KIS government insurance patients to Class $C$ hospitals in Yogyakarta as the first reference for Health Facilities 1. Method: researchers take samples of class C hospital websites in Yogyakarta well government hospitals, social and private organizations. From the hospital website, we analyzed information about insurance and hospital services for BPJS patients. We provide design proposals for the social-CRM model or CRM-2.0 for hospitals by entering BPJS-KIS information on a special menu. In this social CRM model, we offer features that are easily accessible to KIS participants / patients who are in contact with RS social media such as Facebook, Twitter, etc. Results: Form a social CRM proposal for hospitals that are intended by the public who are BPJS-KIS insurance users who can be accessed through RS social media
\end{abstract}

Keywords: Social-CRM Model, Quality Assurance and Hospital Services, BPJS-KIS Patients.

\section{Pendahuluan}

Mengelola hubungan baik terhadap pelanggan merupakan cara perusahaan mengikat loyalitas pelanggan melalui customer relationship management (CRM), terutama perusahan yang bergerak dalam bidang jasa (Jaber \& Simkin, 2017). Dalam CRM prilaku pelanggan merupakan dasar dalam mencari startegi bisnis untuk menjual produk dari suatu institusi dan tidak hanya sebagai sasaran produk. Rumah sakit merupakan institusi yang memberikan pelayanan dituntut untuk selalu 
megutamakan pelayanan yang masksimal, tidak membedakan asal usul, latar belakang pasien, baik pengguna pasien umum asuransi swasta, maupun asuransi pemerintah BPJS-KIS. Seperti dalam perusahaan jasa, tujuan utama CRM pada institusi rumah sakit adalah berpusat pada pelayanan konsumen atau pasien. Terkait pelayanan kesehatan rumah sakit terhadap pasien, tugas CRM tidak hanya menangani pelayaanan untuk pasien umum dan pasien asuransi swasta tetapi juga pasien dengan asuransi pemeritah melalui Kartu Indonesia Sehat (KIS) (Nugraheni \& Kirana, 2018). Bentuk baru crm saat ini merupakan cerminan dari pendekataan terhadap masyarakat melaui social media yang lebih popular disebut social-custumer relationship management (CRM) atau CRM 2.0 (Ahani, Rahim, \& Nilashi, 2017). Sejalan dengan manajemen rantai pasokan dan perencanaan sumber daya perusahaan(Olson, Johansson, \& De Carvalho, 2018), dalam sosial CRM pelanggan memungkinkan terlibat dalam proses peningkatan pelayanan, yang pada akhirnya pelanggan dapat memperoleh solusi layanan yang cepat dan tepat demi kepuasan pasien itu sendiri (Wang, 2018). Sehingga tidak ada anggapan membedakan perlakuan pengguna asuransi BPJS- KIS dengan pasien umum atau asuransi swasta.

Untuk dapat berjalan dengan baik kemampuan layanan sosial-CRM diharuskan mengelola informasi dari pasien dengan baik. Manajemen tersebut terutama dalam penggunaan Informasi, dan semua yang memiliki hubungan positif yang berasal dari informasi pasien malalui media sosial(Wang, 2018)(Mohiuddin AK, 2019). Selain itu, perkembangan crm tidak hanya meningkatkan loyalitas (Ong, Lee, \& Ramayah, 2018) pelanggan melainkan juga menarik calon pelanggan baru (CossíoSilva, Revilla-Camacho, Vega-Vázquez, \& Palacios-Florencio, 2016). Social CRM atau CRM 2.0 dalam rumah sakit memberikan suatu konsep manajemen yang menyuguhkan tingkat kepercayaan pasien kepada rumah sakit dan dapat di akses oleh pasien lain maupun calon pasien baru terutama melalui media sosial (Harrigan, Soutar, Choudhury, \& Lowe, 2015). Ini berarti selain sebagai wadah yang menaungi aspirasi pasien, sosial CRM juga bisa digunakan sebagai startegi promosi rumah sakit (Taqwa et al., 2015a). Dengan asumsi pasien tersebut memberikan review positif pada sosial media terhadap rumah sakit terutama pelayanan RS terhadap pasien penguna BPJS- KIS. Perkembangan aplikasi sosial $C R M$ dewasa ini dipengaruhi oleh pola gaya hidup masyarkat yang cenderung serba mobile, tidak menutup kemungkinan juga untuk pasien rumah sakit. Pengguna internet lebih tertarik mencari informasi lewat sosial media seperti twiter, instagram (Harrigan et al., 2015)(Dewnarain, Ramkissoon, \& Mavondo, 2019), facebook (Mohiuddin AK, 2019)(Marolt, Zimmermann, \& Pucihar, 2018) dan aplikasi sosial media lainya. Meskipun di beberapa website resmi rumah sakit sudah terhubung layanan sosial media sperti twiter, facebook dan instagram, namun tidak banyak info atau konten yang memuat informasi khusus tentang pengunaan asuransi pemerintah BPJS-KIS. Berikut adalah grafik batak peserta JKN gambar 1.

Gambar 1 memperlihatkan grafik peserta JKN, Badan Penyelenggara Jaminan Sosial (BPJS) Kesehatan mencatat total jumlah peserta Jaminan Kesehatan Nasional-Kartu Indonesia Sehat (JKN-KIS) mencapai 222.463.022 jiwa hingga 1 Juli 2019. Jumlah tersebut sebesar $83,94 \%$ dari total penduduk Indonesia. Sedangkan di seluruh provinsi DI. Yogyakarta peserta JKN-KIS 3.409.346 jiwa dari 3.618.084. Untuk dapat menggunkan JKN-KIS di RS, pasien diharuskan mendapatkan persetujuan bertingkat, rujukan dari faskes 1 (puskemas, dokter keluarga, klinik pratama, maupun dokter gigi). Kemudian ke rumah sakit kelas $C$ atau $D$ (rumah sakit status transisi)(Maharani \& Tampubolon, 2018) dan seterusnya, sehingga rumah sakit kelas C dan D merupakan rumah sakit dengan status rujukan pertama pasien pengguna JKN-KIS. Banyak masyarakat yang masih bingung alur pengobatan menggunakan JKN-KIS di rumah sakit sehinnga timbul prasangka membedakan pelayanan (Fitriana, Suryawati, \& Fatmasari, 2018). Dari beberapa website RS kelas $C$ yang dianalisis peneliti juga tidak menemukan menu khusus BPJS-KIS pada website dan tidak banyak menemukan konten penggunaan JKN KIS pada sosial media RS. Ini berdampak pada anggapan masyarkat bahwa RS tidak menerima pasien penguna asuransi pemerintah JKNKIS. 


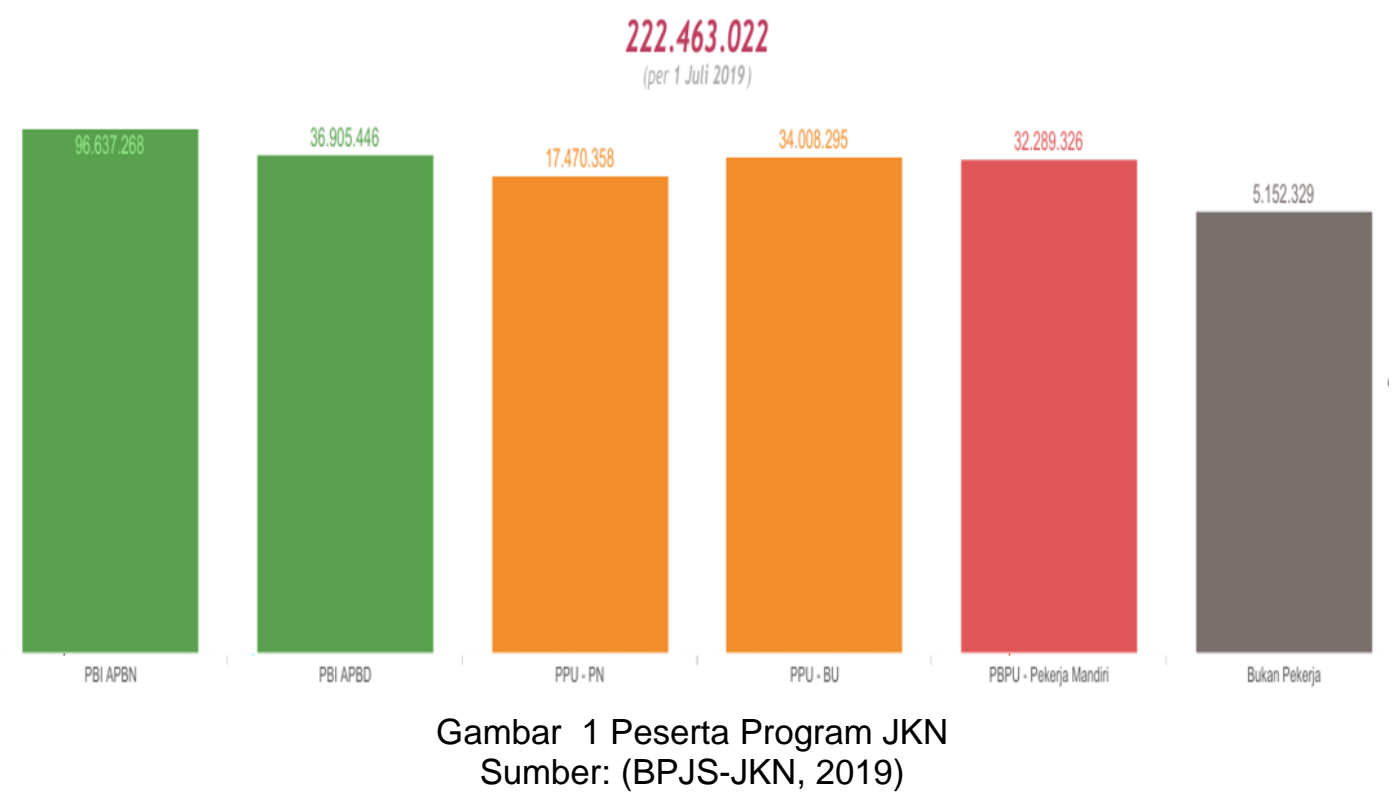

Penelitian ini berfokus pada analisis pemodelan sosial CRM pada rumah sakit khusus pengguna asuransi pemerintah KIS dengan tujuan terciptanya loyalitas (Ong et al., 2018) dan kepercayaan masyarkat kepada rumah sakit sehingga dampak yang muncul nantinya bermafaat bagi rumah sakit dan juga pasien pemegang kartu Indonesia sehat (KIS). Pada penelitian ini, peneliti mengambil beberapa contoh website rumah sakit kelas C di Yogyakarta. Dengan menganalisa penggunaan sosial CRM rumah sakit dalam meningkatkan pelayanan dan kepercayaan pasien pengguna BPJSKIS. Peneliti juga menganalisis konten sosial media rumah sakit dan tingkat respon pasien terhadap pelayanan rumah sakit. Hasil yang didapat dari penelitian ini adalah usulan model sosial CRM yang diperuntukan kepada pasien pengguna asuransi pemerintah BPJS-KIS.

\section{Metode Penelitian}

\subsection{Studi Literatur}

CRM merupakan bentuk dari implementasi service terhadap pelanggan dengan mengutamankan keinginan pelanggan, mempertahnkan loyalitas pelanggan (Wang, 2018). Di beberapa penelitian penelitian terdahulu mempresentasikan bentuk dari crm di era digital yang antara lain adalah E-CRM dan crm 2.0 atau yang lebih dikenal dengan social-CRM (Taqwa et al., 2015a) . Terdapat literatur yang menjelakan bahwa banyak perusahaan jasa yang mengimplementasikan produk social crm unutk mengetahui keinginan pelanggan selain itu mempertahankan loyalitasnya (Muzakki \& Faroqi, n.d.). Dalam literatur yang ditulis Jafari Navimipour, et al., tahun 2016, menjelaskan faktor yang memperngaruhi kesuksesan sebuah institusi atau organisasi dapat dilihat dari penggunaan teknologi e-crm dalam upaya menarik hubungan pelanggan elektronik ( $E$ CRM) (Jafari Navimipour \& Soltani, 2016).

Pada penelitian yang dilakukan Nugraheni, et al., pada tahun 2018 dengan metode sampel yang diambil adalah pasien rawat inap menghasilkan kesimpulan bahwa kepuasan pasien BPJS dalam pelayanan rawat inap di Rumah Sakit X Kediri berdasarkan kualitas pelayanan (Nugraheni \& Kirana, 2018). Sedangkan pada penelitian yang dilakukan oleh Maharani, et al. pada tahun 2018 dengan area yang sama yaitu rumah sakit, menyelidiki konsekuensi korporatisasi rumah sakit, nilai-nilai kerja, kepuasan kerja yang berdampak pada pelayanan pasien. Penelitian dilakukan di 54 rumah sakit umum di Jawa Timur, Indonesia (Maharani \& Tampubolon, 2018). Penelitian dengan obyek pasien rumah sakit juga dilakukan bertujuan untuk menguji dan menjelaskan pengaruh layanan variabel perusahaan kualitas, kinerja perusahaan yang dirasakan oleh pelanggan, citra perusahaan terhadap kepuasan dan loyalitas pelanggan (Perusahaan et al., 2018). 
Pada penelitian yang dilakukan Dewi, et al. pada tahun 2018 meneliti tingkat kepuasan peserta asuransi JKN terhadap layanan rumah sakit. Dengan metode kuantitatif dengan desain penelitian cross sectional terhadap 200 pasien yang terdiri dari pasien BPJS dan pasien umum, dengan hasil bahwa keduanya diklasifikasikan ke dalam tingkat kepuasan yang rendah (Dewi \& Ramadhan, 2018). Terdapat penelitian tentang kepuasan dan loyalitas pasien di Klinik Utama yang menunjukkan bahwa layanan klinis, proses perawatan klinis dan teknologi layanan klinis mempengaruhi kepuasan pasien (Qomariah, 2016). Beberapa literatur juga menjelakan penggunaan CRM dan sosial CRM meningkatkan loyalitas pelanggan terhadap produk yang di tawarkan institusi atau perusahaan terutama intsitusi/perusahaan yang bergerak di bidang jasa seperti perhotelan dengan menggunakaan teknologi informasi(Marolt et al., 2018) (Qomariah, 2016)(Souri, Rahmani, Navimipour, \& Rezaei, 2019). Penelitian tentang pemggunaan sosial media seperti facebook, twiter, Instagram dan lainya untuk menjaring konsumen atau melakukan penawaran sebagai startegi bisnis perusahaan banyak dilakukan saat selain sebagai cara mengikat loyalitas pelanggan (Harrigan et al., 2015) (Dewnarain et al., 2019).

Dari acuan literatur diatas, penelitian ini mengulas peran social-CRM terhadap dalam rumah sakit kelas $C$ sebagai rujukan pertama dari faskes 1 untuk pasien dengan asuransi pemerintah BPJS-KIS. Dengan analisis sosial-CRM memberikan model social-CRM pada $R S$ kelas $C$ yang bertujuan mengikat dan meningkatkan kepercayaan pasien pengguna asuransi pemerintah.

\subsection{Metode}

Pada penelitian ini bersifat analisis explanatory(penjelasan) dan rekomendasi model sosial CRM yang diharapkan mampu menangani anggapan negatif tentang pelayan rumah sakit terutama pasien dengan asuransi pemerintah JKN. Dengan memasukan unsur media sosial dimana hampir 80 pengguna ponsel saat ini mengakses social media.

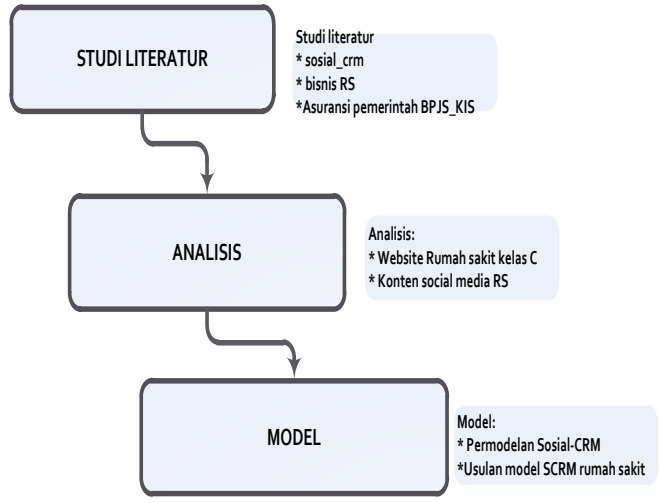

Gambar 2 Metode Penelitian

Pada gambar 1 memperlihatkan metode penelitian, dimana jalannya penelitian meliputi:

1. Studi literatur

Penelitian ini dimulai dengan mencari informasi melalui jurnal sebelumnya mengenai CRM, social CRM, bisnis dan manajemen rumah sakit, layanan rumah sakit serta asuransi pemerintah BPJSKIS,

2. Analisis

Kami menganalisis beberapa website resmi dan social media rumah sakit kelas C di Yogyakarta secara online. Konten dari website maupun media sosial rumah sakit menjadi acuan penelitian ini dengan tujuan mengetahui tingkat frekuensi informasi mengenai asuransi JKN untuk pelanggan rumah sakit. Keterlibatan unsur media sosial dalam beberapa website sangat penting dimana prilaku pasien terutama pasien BPJS dapat di ketahui sehingga dapat menciptakan strategi pemasaran rumah sakit.

Pada gambar 3 merupakan salah satu contoh website dan sosial media rumah sakit yang bertipe $C$. Rumah sakit tipe $C$ merupakan rumah sakit rujukan pertama dari faskes 1 selain rumah sakit tipe D. Dapat dilihat bahwa website rumah sakit tersebut sudah terhubung dengan sosial media yang menurut analisa kami kontennya selalu terbaharui meskipun tidak meanampilkan isi konten yang diperuntukan pasien KIS. 


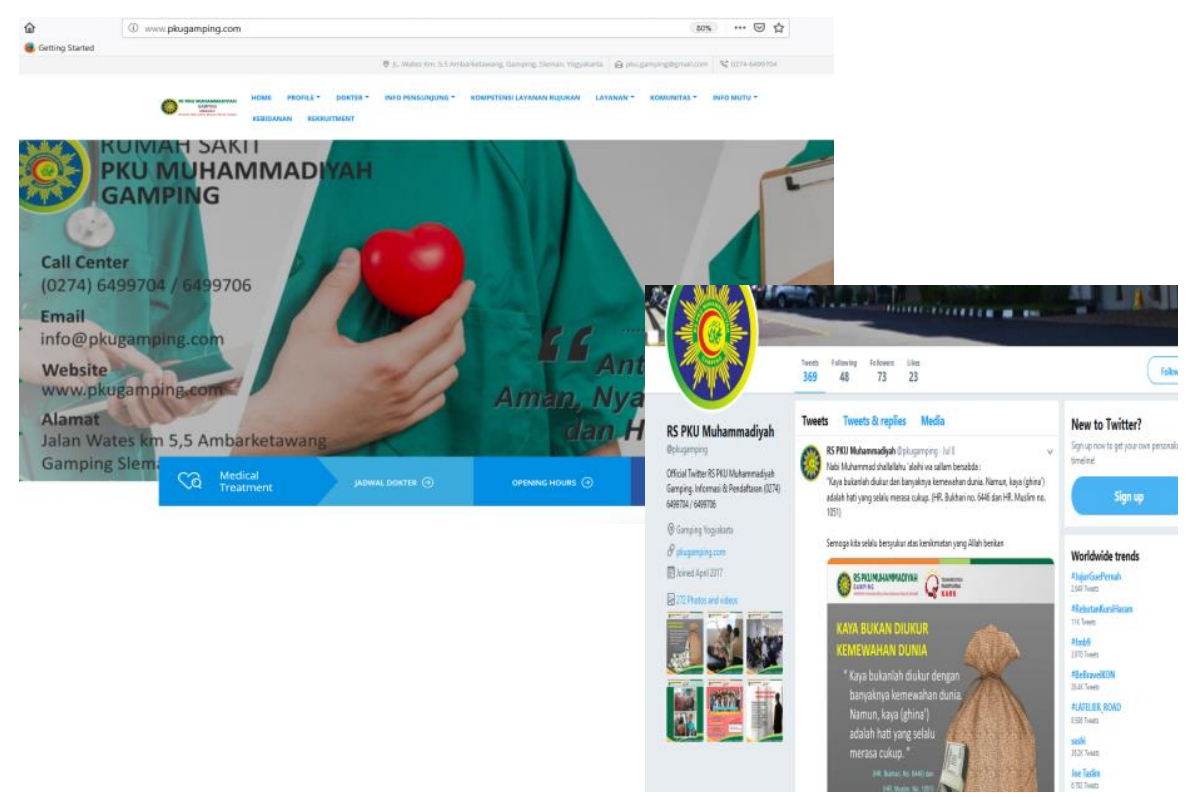

Gambar 3 Salah Satu website dan sosial media RS kelas C di Yogyakarta Sumber: Website RS PKU Gamping Yogyakarta (2019)

3. Rekomendasi berbasis social-crm untuk RS

Pada langkah ketiga dilakukan pemodelan SCRM pada dinas pada rumah sakitkelas $C$. Mengacu pada literature sebelumnya
(Harrigan et al., 2015)(Dewnarain et al., 2019)(Souri et al., 2019)(Liawatimena, Arifianto, Saliu, \& Salim, 2017) peneliti mengusulkan framework seperti pada gambar 4.

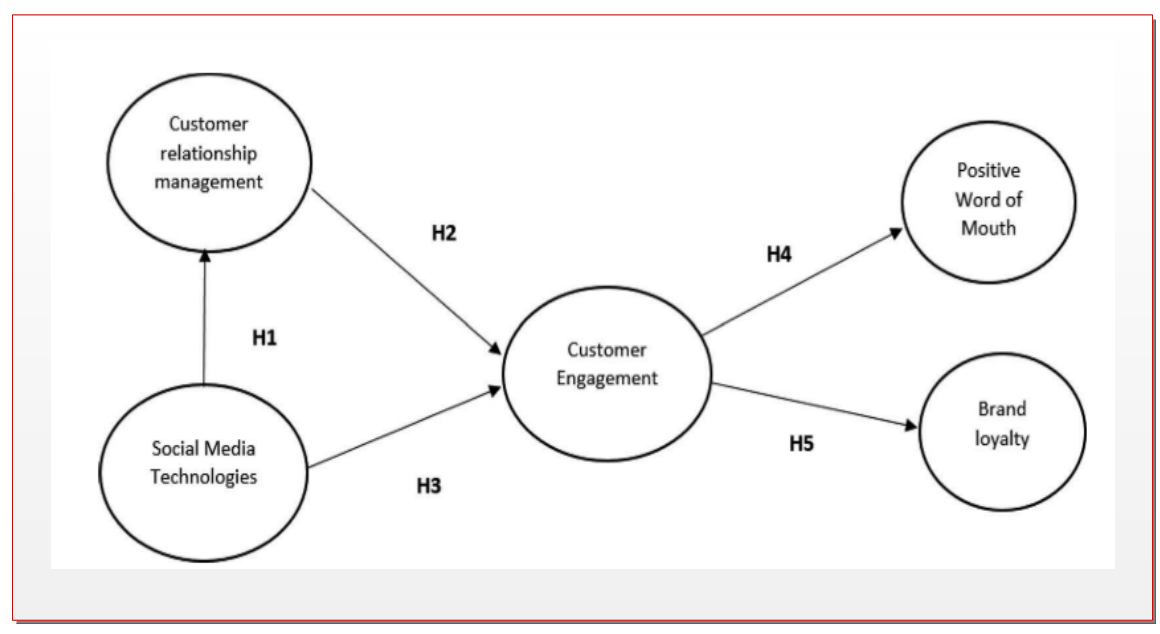

Gambar 4 Framework Social-CRM

Sumber: (Dewnarain et al., 2019)

Pada gambar 4 menjelaskan peran CRM untuk mengatasi hubungan antara manajemen pelanggan, teknologi media sosial, keterlibatan pelanggan yang menginformasikan berita positif dari mulut ke mulut, dan loyalitas terhadap produk yang dijual. Peran media sosial memungkinkan perusahaan untuk terhubung dan 
berkomunikasi dengan pelanggan lama dan menciptakan potensi pelanggan baru. Keterlibatan pelanggan mengarah pada proses penciptaan nilai produk yang dijual baik dalam bentuk jasa maupun barang. Peran sosial CRM untuk pelanggan lama meningkatkan loyalitas terharap merek baik melalui pembelian berulang. Selain itu peran pelanggan lama yang mengakses sosial media dapat mempromosikan keterlibatan pelanggan baru.

Seringnya perubahan tata cara layanan asuransi BPJS di rumah sakit memberikan respon yang kurang baik terhadap RS dari pasien. Dari gambar 4, penelitian ini merekomendasikan usulan penggunaan sosial CRM pada rumah sakit kelas C dengan target masyarakat pengguna asuran BPJS-KIS. Berdasarkan literatur

\section{Hasil dan Pembahasan}

Dari studi literatur dan analisis terhadap website dan sosial media rumah skait kelas $\mathrm{C}$, penelitian ini menemukan. bahwa kualitas layanan dan loyalitas pelanggan. pengguna produk jasa bisa dipengaruhui oleh sosial sebelumnya dan mengadopsi framework sosial-CRM, penelitian ini memnafaatkan analisis brand loyalty RS kelas C yang berasal dari serapan informasi masyarakat melalui media sosial rumah sakit kelas $C$ mengenai asuransi BPJS. Nantinya rumah sakit bisa menrekomendasikan layanan seperti menu khusus pada web tentang pelayanan pengguna asuransi BPJS-KIS di rumah sakit kelas $\mathrm{C}$. Dari menu khusus yang terhubung ke sosial media ini pasien dapat mengakses informasi melalui akun social media mereka tentang informasi terbaru pelayanan BPJS di rumah sakit tempat mereka berobat. Sehingga manajemen rumah sakit dalam hal ini devisi CRM nya bisa memberikan usulan pelayan baru yang bisa memprioritaskan service ke pasien

media. Pada pengguna asuransi pemerintah JKN seharusnya menjadi prioritas rumah sakit tertutama rumah sakit kelas $C$ sebagai rujukan pertama faskes 1 . Pemerintah sendiri telah bekerjasama di hampir semua rumah sakit di Indonesia baik RS negeri, maupun swata.

\subsection{9}

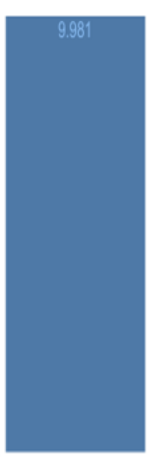

Puskesmas

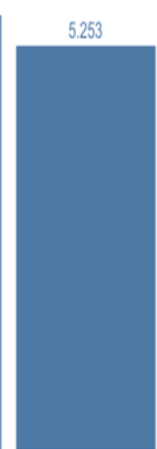

Dokter Prakter Perorangan

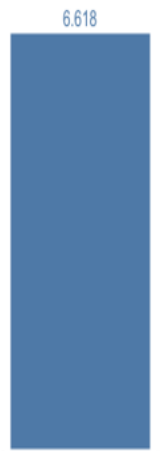

Klinik Pratama

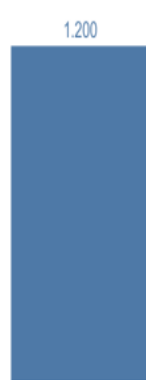

Dokter Gigi

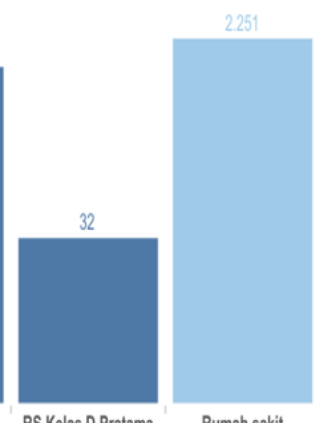

Rumah sakit

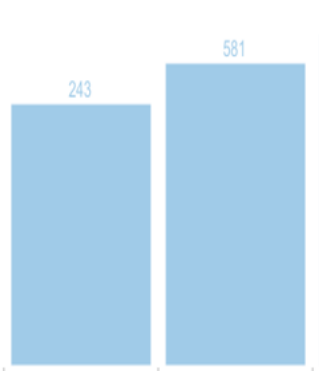

Klinik Utama Apotik PRB dan Kronis

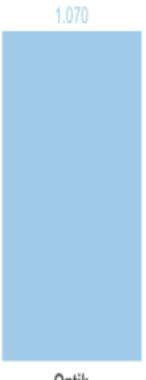

Optik

Gambar 5 Grafik Fasilitas Kesehatan JKN

Sumber: (BPJS-JKN, 2019)

Gambar 6 Grafik Fasilitas Kesehatan JKN

Pada gambar 5 merupakan diagram yang menunjukan jumlah fasilitas kesehatan di seluruh Indonesia yang bekerja sama denga BPJS yang berjumlah 27.229 fasilitas. Fasilitas kesehatan tersebut meliputi faskes 1 yaitu Puskesmas, dokter praktek perorangan, klinik pratama, klinik utaman, dan dokter gigi. Sedangkan faskes 2 merupakan faskes rujukan yaitu RS kelas dan C. Selanjutnya rumah sakit B atau A yang menjadi rujukan akhir. Menurut halaman website resmi kementrian kesehatan saat ini terdapat 82 rumah sakit yang ada di Yogyakarta, meliputi kelas A, B, $\mathrm{C}$, dan D. Dan dari 82 rumah sakitt tersebut terdapat 29 rumah sakit bertipe $\mathrm{C}$ 
Tabel 1 Rumah sakit kelas C di Yogyakarta

\begin{tabular}{|c|c|c|c|c|}
\hline Daerah & $\begin{array}{l}\text { Rumah } \\
\text { Sakit }\end{array}$ & $\begin{array}{l}\text { RS kelas C } \\
\text { Rujukan } \\
\text { BPJS_KIS }\end{array}$ & $\begin{array}{l}\text { Website } \\
\text { dan } \\
\text { Social } \\
\text { Media RS }\end{array}$ & $\begin{array}{l}\text { Tidak } \\
\text { mempunyai } \\
\text { website- } \\
\text { social } \\
\text { media }\end{array}$ \\
\hline $\begin{array}{c}\text { Kota } \\
\text { Yogyakarta }\end{array}$ & 10 & 10 & 9 & 1 \\
\hline Sleman & 8 & 8 & 6 & 2 \\
\hline Kulon Progo & 0 & 0 & 0 & 0 \\
\hline Gunung kidul & 1 & 1 & 1 & 0 \\
\hline Bantul & 10 & 10 & 6 & 4 \\
\hline Jumlah & 29 & 29 & 20 & 9 \\
\hline
\end{tabular}

Pada tabel 1, memperlihatkan jumlah rumah sakit kelas $\mathrm{C}$ yang ada di Yogyakarta. Rumah sakit ini merupakan rumah sakit yang menjadi rujukan pertama dari faskes 1 selain rumah sakit kelas $D$. Rumah sakit kelas $C$ ini berdiri di 3 kabupaten - kota dan hanya satu daerah yang tidak memiliki rumah sakit kelas C yaitu daerah Gunung kidul. Dari 29 rumah sakit kelas C ini merupakan milik pemkab, polri, organisasi sosial dan swasta. Dari pengamatan, sebagian besar rumah sakit kelas $C$ di Yogyakarta telah memiliki website resmi dan juga akun sosial media, namun tidak banyak dipergunakan untuk informasi seputar
BPJS. Sedangkan cakupan peserta JKNKIS di Yogyakarta, berjumlah 3.409.346 jiwa dari 3.618.084 jiwa.

Mengacu pada literatur dan pada framework social-CRM dengan mengedepankan loyalitas pasien bpjs. Penelitian ini mengusulkan model social CRM dengan memanfaatkan sosial media melalui website dan social media rumah sakit kelas C. Tujuan memanfaatkan media sosial sebagai media untuk menyerap informasi dari pasien pengguna asuransi BPJS-KIS.

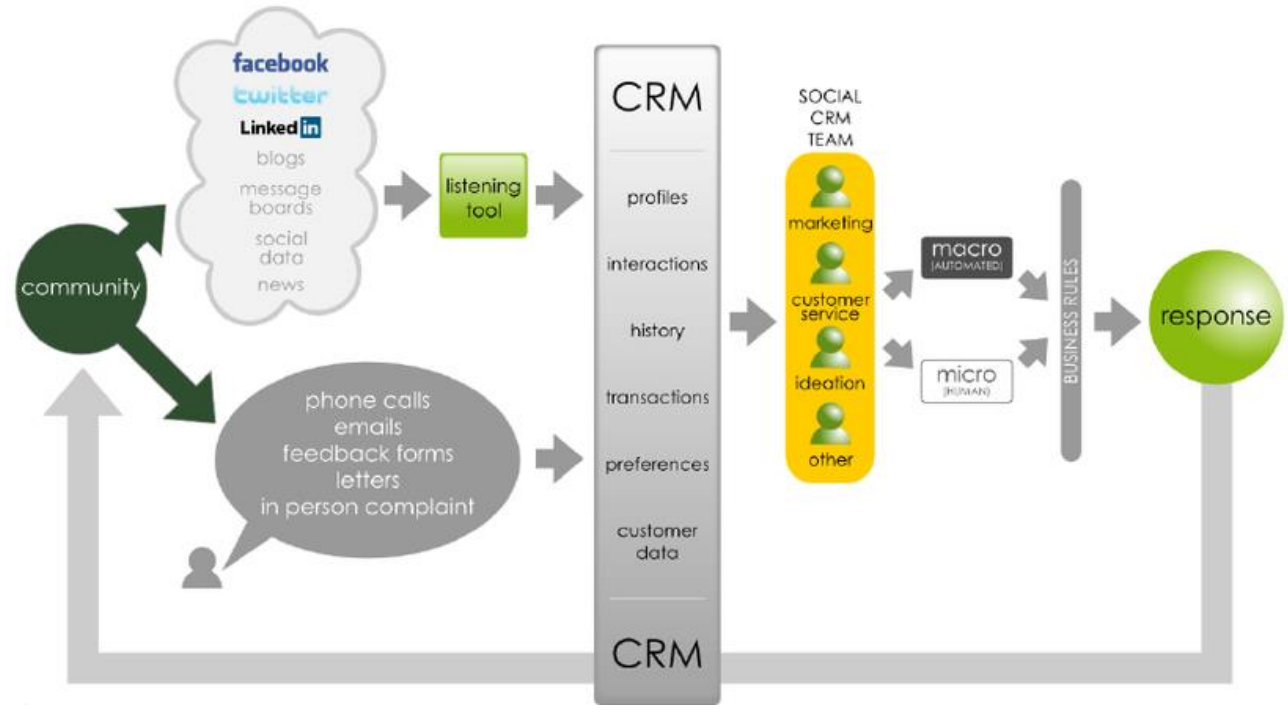

Gambar. 6 Proses sosial-CRM

Sumber: (Taqwa et al., 2015) 
Gambar 6 memperlihatkan proses sosial crm dalm model ini diproyeksikan sudah ada social CRM team yang mengolah serapan informasi dari seluruh pasien rumah sakit terutama pasien dengan asuran JKN dan mengemasnya menjadi pengetahuan yang nantinya dijadikan toalk ukur dalam pelayanan rumah sakit dan dapat dijadikan strategi bisnis. Saat ini semua orang hampir menggunakan media sosial untuk bersosialisi dan juga ada yang melakukan promosi produk. Faktanya lebih dari 3 miliar orang saat ini aktif dengan situs media sosial seperti Twitter, Facebook, Instagram dan Youtube.

Kami mengusulkan model website atau aplikasi seluler yang terdapat menu khusus BPJS-KSI yang terhubung ke layanan sosial media dengan anggapan bahwa para pasien lebih banyak mengakses social media. Pasien bpjs juga dapat menyalurkan aspirasi dan keluh kesah dengan tentang pelayanan rumah sakit melalui wadah model social crm yang berupa social media rumah sakit sperti instagram fb twiter dll. Pengetahuan yang didapat dari social media pasien akan membantu pembuat kebijakan rumah sakit ketika merencanakan program kerja rumah sakit rumah sakit kelas $C$ di Yogyakarta. Dalam ruang media sosial keluhan, komentar dan saran dari wisatawan jika disikapi dengan baik akan menjadi asset bagi RS untuk melakukan perbaikan sehingga kepuasan pasien BPJS terpenuhi dan menghilangkan anggapan negative terhadap rumah skait.

\section{Kontribusi}

Dalam makalah ini peneliti mengusulkan bentuk model social-crm pada rumah sakit untuk kebutuhan pasien pengguna asuransi pemeritah BPJS-KIS dalam rangka meningkatkan kepercayaan dan loyalitas pasien RS. Kontribusi ini diharapkan memberikan pengetahuan yang signifikan untuk literatur CRM dalam lingkungan rumah sakit.

\section{Kesimpulan}

Dari studi literatur dan explanatory(penjelasan) beberapa website RS dan sosial media RS di Yogyakarat penelitian ini menyimpulkan bahwa sebagian besar RS tipe $C$ tidak mempromosikan asuransi pemerintah BPJS-KIS dengan baik. Dengan mengusulkan model sosial-CRM diharapkan memberikan masukan pada RS di Yogyakarta terutama RS kelas C dalam memberikan pelayanan yang maksimal kepada seluruh pasien tanpa membedakan jenis pasien. Penelitian ini juga memberikan pengetahuan yang signifikan untuk manajemen CRM dalam lingkungan rumah sakit. Social-CRM atau CRM2.0 berdasarakan teori komunikasi pemasaran produk layanan rumah sakit dan model Social-CRM. Diharapkan bentuk model social-crm pada rumah sakit untuk kebutuhan pasien pengguna asuransi pemeritah BPJS-KIS dalam rangka meningkatkan kepercayaan dan loyalitas pasien RS tipe $\mathrm{C}$ sebagai rujukan faskes.

\section{Referensi}

Ahani, A., Rahim, N. Z. A., \& Nilashi, M. (2017). Forecasting social CRM adoption in SMEs: A combined SEMneural network method. Computers in Human Behavior, 75, 560-578. https://doi.org/10.1016/j.chb.2017.05.0 32

BPJS-JKN. (2019). BPJS-JKN. Retrieved from https://faskes.bpjskesehatan.go.id/aplicares/\#/app/peta

Cossío-Silva, F. J., Revilla-Camacho, M. Á., Vega-Vázquez, M., \& PalaciosFlorencio, B. (2016). Value co-creation and customer loyalty. Journal of Business Research, 69(5), 16211625.

https://doi.org/10.1016/j.jbusres.2015. 10.028

Dewi, A., \& Ramadhan, N. K. (2018). The Difference of Satisfaction Level in BPJS Health Insurance Patient and Non Insurance Patient toward Health Service. International Journal of Public Health Science (IJPHS), 5(1), 36. https://doi.org/10.11591/.v5i1.4760

Dewnarain, S., Ramkissoon, H., \& Mavondo, F. (2019). Social customer relationship management: An integrated conceptual framework. Journal of Hospitality Marketing and Management, 28(2), 172-188. https://doi.org/10.1080/19368623.201 8.1516588

Fitriana, R. N., Suryawati, C., \& Fatmasari, E. Y. (2018). Analisis Perbedaan Persepsi Pasien Umum Dan Bpjs Terhadap Tingkat Responsiveness 
Pelayanan Rawat Jalan Di Rumah Sakit Umum Daerah Tugurejo Semarang. Jurnal Kesehatan Masyarakat, 6(5), 145-156.

Harrigan, P., Soutar, G., Choudhury, M. M., \& Lowe, M. (2015). Modelling CRM in a social media age. Australasian Marketing Journal, 23(1), 27-37. https://doi.org/10.1016/j.ausmj.2014.1 1.001

Jaber, F., \& Simkin, L. (2017). Unpicking antecedents of CRM adoption: a twostage model. Journal of Strategic Marketing, 25(5-6), 475-494. https://doi.org/10.1080/0965254X.201 6.1149212

Jafari Navimipour, N., \& Soltani, Z. (2016). The impact of cost, technology acceptance and employees' satisfaction on the effectiveness of the electronic customer relationship management systems. Computers in Human Behavior, 55, 1052-1066. https://doi.org/10.1016/j.chb.2015.10.0 36

Liawatimena, S., Arifianto, T., Saliu, Y., \& Salim, H. A. (2017). Analisis Customer Relationship Management terhadap Kepuasan Pasien Pusat Jantung Nasional Harapan Kita. The Winners, 3(1), 56. https://doi.org/10.21512/tw.v3i1.3832

Maharani, A., \& Tampubolon, G. (2018). Does corporatisation improve organisational commitment? Evidence from public hospitals in Indonesia. International Journal of Human Resource Management, 29(13), 19992026.

https://doi.org/10.1080/09585192.201 6.1239121

Marolt, M., Zimmermann, H. D., \& Pucihar, A. (2018). Exploratory study of social CRM use in SMEs. Engineering Economics, 29(4), 468-477. https://doi.org/10.5755/j01.ee.29.4.20 246

Mohiuddin AK. (2019). Patient Relationship Management: Patient Care with CRM Approach. PharmaTutor, 7(4), 22-36. https://doi.org/http://dx.doi.org/10.291 61/PT.v 7.14 .2019.22

Muzakki, A., \& Faroqi, A. (n.d.). Faktor Sukses Implementasi CRM Software pada Perusahaan Jasa. Jurnal IImiah Bidang Teknologi Informasi Dan Komunikasi.

Nugraheni, R., \& Kirana, G. R. (2018). The
Analysis Quality of Service and Patient Satisfaction Participants of Health BPJS in Interior Services in Hospital $X$ of Kediri City. The Analysis Quality of Service and Patient Satisfaction Participants of Health BPJS in Interior Services in Hospital $X$ of Kediri City, 3(1), 9-17.

Olson, D. L., Johansson, B., \& De Carvalho, R. A. (2018). Open source ERP business model framework. Robotics and Computer-Integrated Manufacturing, 50, 30-36. https://doi.org/10.1016/j.rcim.2015.09. 007

Ong, C. H., Lee, H. W., \& Ramayah, T. (2018). Impact of brand experience on loyalty. Journal of Hospitality Marketing and Management, 27(7), 755-774. https://doi.org/10.1080/19368623.201 8.1445055

Perusahaan, C., Loyalitas, T., Melalui, P., Sakit, R., Sultan, I., \& Semarang, A. (2018). Analisis Pengaruh Kualitas Layanan, Harapan Kinerja dan Citra Perusahaan Terhadap Loyalitas Pelanggan Melalui Kepuasan Pelanggan Sebagai Variabel Intervening (Studi Ppda Rumah Sakit Islam Sultan Agung Semarang). Diponegoro Journal of Management, 7(1984).

Qomariah, N. (2016). Pengukuran Kepuasan Dan Loyalitas Pasien Rumah Sakit. Seminar Nasional UMS, 239-250.

Souri, A., Rahmani, A. M., Navimipour, N. J., \& Rezaei, R. (2019). Formal modeling and verification of a service composition approach in the social customer relationship management system. Information Technology and People. $\quad$ https://doi.org/10.1108/ITP02-2018-0109

Taqwa, P., Jean, D., Sihombing, C., Bata, J., Informasi, S., Mercubuana, U., ... Utara, P. S. (2015a). Model Social Crm Sebagai Strategi Bisnis Pariwisata Provinsi Sumatera Utara. Seminar Nasional Informatika 2015, 2015(November), 245-251.

Taqwa, P., Jean, D., Sihombing, C., Bata, J., Informasi, S., Mercubuana, U., ... Utara, P. S. (2015b). Model Social Crm Sebagai Strategi Bisnis Pariwisata Provinsi Sumatera Utara, 2015(November), 245-251.

Wang, M. L. (2018). Linking CRM to 
customer-oriented behaviour through service climate perceptions. International Journal of Business and Systems Research, 12(3), 243. https://doi.org/10.1504/ijbsr.2018.1001 1344

Yunitarini, R., Budi, P., \& Nurwarsito, H. (2012). Implementasi Perangkat Lunak Electronic Customer Relationship Management ( E-CRM ) dengan Metode Framework of Dynamic CRM. Jurnal EECCIS, 6(1), 83-90. 